\title{
ヘプタフルオロイソプロピル=ベンゾアートおよびベンジル= ヘプタフルオロイソプロピル=エーテル類の合成と性質
}

（1974 年 11 月 13 日受理）

石 川 延男・大 沢 正*

ヘキサフルオロアセトンとフルオリドイオンとから生成するへプタフルオロイソプロボキシドイオン を求核試剂として用い，これと八ロゲン化ベンゾイルおよび八ロゲン化ベンジルとの反応について検討 した。

ハロゲン化ベシソイルとの反応熱力学的に制御され， $0^{\circ} \mathrm{C}$ 付近の低温に和いてのみへプタフルオロ イソプロピルニペンソ゚フートを収率よく生成したが，この生成物もフルオリドイオンによって容易にも とへもどることがわかった。

$$
\begin{aligned}
& \left(\mathrm{CF}_{3}\right)_{2} \mathrm{C}=\mathrm{O}+\mathrm{F} \odot \rightleftharpoons\left(\mathrm{CF}_{3}\right)_{2} \mathrm{CF}-0 \Theta \\
& \mathrm{PhCOX}+\left(\mathrm{CF}_{3}\right)_{2} \mathrm{CF}-\mathrm{O} \odot \rightleftharpoons \mathrm{PhCO}_{2} \mathrm{CF}\left(\mathrm{CF}_{3}\right)_{2}+\mathrm{X}^{\ominus}
\end{aligned}
$$

八ロゲン化ベンジルとの反応はこれと奶照的に 80 ～85 C のような比較的高い温度を必要とし，よい 取率で安定なベンジルニヘプタフルオロイソプロピルニエーテルを生成した。

$$
\mathrm{PhCH}_{2} \mathrm{X}+\left(\mathrm{CF}_{3}\right)_{2} \mathrm{CF}-\mathrm{O} \odot \longrightarrow \mathrm{PhCH}_{2} \mathrm{OCF}\left(\mathrm{CF}_{3}\right)_{2}+\mathrm{X} \odot
$$

ベンゼン環に置換基をすつ八ロゲン化ベンジル類も同様な条件下で反応し，p-メチル括よび $m-$, $p-7$ ルオロ，クロロ，拉よびニトロベンジルヘプタフルオロイソプロピルニエーテルがいずれる実用的な取 率で得られた。

$m$-および $p$-フルオロ誘導体の ${ }^{19} \mathrm{~F} \mathrm{NMR}$ 化学シフト值から置換基としての $\mathrm{CH}_{2} \mathrm{OCF}\left(\mathrm{CF}_{3}\right)_{2}$ の $\sigma_{\mathrm{g}}{ }^{0}$ お゙よび $\sigma_{\mathrm{I}}$ 值をそれぞれ -0.01 および+0.19 ときめた。

\section{1 藉㝜}

へキサフルオロアセトン(以下 HFA と略記する)はその興味あ る反応性のために，合成原料として用いた例がしだいK多く報告 されるようになっだ。

HFA をイオン的な反応試薬として用いる方法として，一つは カルボニル炭素の強い陽性を利用して求電子試薬として働かせる 場合，他の一つはフッ化アルカリ金属を作用させてへプタフルオ ロイソプロポキシドイオンをつくらせ，これを求核試薬として働 かせる場合の二つが考光られる。前者の例は比較的多く研究され ているが，後者の例忙との数怯いま大がぎらている。その理由 は, ヘプタフルオロイソプロポキシドイオンの求核性がきわめて 弱いととななら゙にーブタフルオロイソブロポキシドイオンが HFA と可逆的な平衡をたるっていて熱的に不安定である2ことな どあるら。

しかしながら，このペルフルオロアルコキシドイオンは，活性 な有機ハロゲン化合物と反応して物性的に興味あるープタフルオ

* 東京工業大学工学部化学工学科, 152 東京都目黑区大间山

1）総説 : C. G. Krespan, W. J. Middleton, "Fluorine Chemistry Reviews", Vol.1, Marcell Dekker(1967)p. 145.

2) M. E. Redwood, C. J. Wills, Can. J. Chem., 45, 389 (1967).
ロイソプロピルエステルやエーテルをつくる。たとえばアクリル 酸クロリドからは，はっ水; はつ油性をるつ織䧽处理剂のモノマ 一であるフクリル酸へブタフルオロイソプロピルエステルが、, また塩化ベンゼンスルホニルや塩化ヘンゾイルからは, 耐酸化性 のよい液体, ヘブタフルオロイソプロピルエステルが得られてい 万)。

著者らは種々の誘導体へ導く可能性をそなえた合成中間体とし て、芳香核るつープタフルオロイソブロポキシル化合物の合成 をるくろみ，まずハロゲン化ベンゾイルおよびベンジルならびに その核㹂換体位するへブタフルオロイソプロポキシドイオンの 求核反応について検討した。

\section{2 結果と考案}

2.1 塩化ベンソイルとヘブタフルオロイソブロボキシドイオ ンとの反応

HFA とフッ化アルカリ金属とは，非ブロトン性極性溶媒中て つぎの一般式にしたがって付加物を生成することが知られてい る。

3) A. G. Pittman, D. L. Sharp, Textile Res. J., 35, 190 (1965).

4) C. I. Merrill, U. S. P., 3, 658, 872(1972). 


$$
\begin{gathered}
\mathrm{CF}_{3} \\
\mathrm{CF}_{3}
\end{gathered}>\mathrm{C}=\mathrm{O}+\mathrm{MF} \rightleftarrows{\stackrel{\mathrm{CF}}{\mathrm{CF}_{3}}>\mathrm{CF}-\mathrm{O} \mathrm{M}^{\oplus}}_{\mathrm{M}=\mathrm{K}, \mathrm{Rb}, \mathrm{Cs}}
$$

Redwood らは, 単離したアルカリ金属へプタフルオロイソプ ロポキシドは，温度に対して鋭敏で，20ㄷ 以下では安定である が、これより温度が上がるとすみやかに HFAとフッ化フルカリ 金属に分解すると報告しているッ。和とらく有機溶媒中でもへブ タフルオロイソブロポキシドイオンの同様な不安定さが考えら れこのアニオンを求核陚剂とする反応にさいしては平衡論的な 意味では反応温度を低くする方がのぞましいと思われる。著者ら はまず基質として求核試丳の攻撃をきわめて受けやすい塩化ベン ソ゚イルをえらんで反応温度の影敏を検討した。

この反応は，最近の特許文献中心に一例としての記載があり， 塩化ベンゾイルと HFA をフッ化カリウムの存在下ジグライム中 室温以下で反応させて，へプタフルオロイソプロピルニベンゾフ ートニエステルを得たと述べられている。著者らは表 1 に示した 条件下に温度を変えてこの反応を行ない，それそれの収率を比較 した。

その結果, $0^{\circ} \mathrm{C}$ 付近ではほぼ定最的にヘプタフルオロイソプロ ピルエステルが得られたが， $45^{\circ} \mathrm{C}$ に拈いてはその収率はいちじ るしく低下し，末反応物が安息香酸として多量に回収された。後 者の原因としてさきに述へたへブタフルオロイソプロポキシドイ オンの平衡のほかにつぎに示す可逆的な平衡が考えられた。

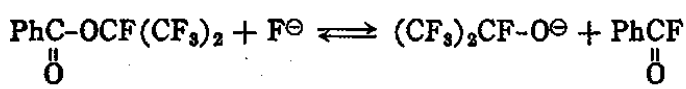

実䏅に単離したエステルをフッ化カリウムとジグライム中 45 ${ }^{\circ} \mathrm{C}$ で反応させたところ，1時間以内にフッ化ベンゾイルに分解さ れることがわかった。したがって上に述べた反応は温度が高いと 熱力学的に抑制されて収率が低くなることがかかった。

またこのようにして得られたへプタフルオロイソプロピルニペ ソゾフートニエステルの酸, アルカリに対する安定性を検討した が，予期されたようにこのエステルはアルカリによってきわめて 容易に加水分解された。すなわら水酸化ナトリウムの希エタノ一 ル溶液中，室温で瞬間的に加水分解され，安息香酸を生成した。 酸に対してはかなり安定で塩酸エタノール混液中還流下で反応さ せたところ, 約 15 時間でほぼエステルはなくなり安息香酸が生 成してきた(ガスクロマトグラフ分析)。

ついて熱に対する安定性について検討した。95〜100C Kエス テルをたるったときは，2時閻で変化がみられなかったが， $130^{\circ} \mathrm{C}$ K加熱すると約 20 分で分解し始め, 35 分では完全にフッ 化ベンソ゚イルK分解した。

また同様にして二塩化テレフタロイルと HFA との反応をフッ 化カリウムの存在下室温で行なわせた結果，ジエステルが好取率

Table 1 Reaction between $\mathrm{PhCOCl}$ and $\left(\mathrm{CF}_{3}\right)_{2} \mathrm{CF}-\mathrm{O}^{-}$ $\mathrm{PhCOCl}(0.03 \mathrm{~mol}), \mathrm{HFA}(0.039 \mathrm{~mol}), \mathrm{KF}(0.03 \mathrm{~mol})$, were reacted in diglyme $(10 \mathrm{ml})$

\begin{tabular}{ccccc}
$\underset{\begin{array}{c}\text { Temp. } \\
\left({ }^{\circ} \mathrm{C}\right)\end{array}}{\text { Reaction condition }}$ & $\begin{array}{c}\text { Time } \\
(\mathrm{hr})\end{array}$ & $\overbrace{i-\mathrm{C}_{8} \mathrm{~F}_{7} \text { Ester }}^{(\%)}$ & $\begin{array}{c}\text { Yield of povd. } \mathrm{PhCO}_{2} \mathrm{H} \\
(\%)\end{array}$ \\
\hline 0 & 6 & 94 & - \\
25 & 6 & 77 & 17 \\
45 & 6 & 39 & 47
\end{tabular}

(87\%) で得られた。しかしこのジェステルるアルカリによって 容易に加水分解され，たとえばエタノール中希水酸化ナトリウム 水溶液と室温でかきまぜるだけで，ただらにテレフタル酸ナトリ ウムを生成した。しかし熱に対しては安定で， $180^{\circ} \mathrm{C} に 1$ 時間た るってるなんら変化は悐められなかった。

Pittman らはプロピオン酸ヘプタフルオロイソプロピルエステ ルが室温でさえす分解すると報告しておりす，これにくらべれば 芳香族カルポン酸エステルはかなり熱に対して安定であるといえ る。

2.2 ヘブタフルオロイソプロボキシドイオンと臭化ベンジル との反応

2.1 で述べたよらにカルボン酸のへプタフルオロイソプロピル エステルはアルカリによってきわめて加水分解されやすく，実用 的な意味で化学的に安定な化合物としての用途は少ないと考えら れる。そこでハロゲン化ベンジルとヘプタフルオロイソプロポキ シドイオンとの反応によるベンジルニヘプタフルオロイソプロピ ルニエーテル類の合成とその性質について検討した。

一般にハロゲン化ペンジルは，ハロゲン化ベンゾイルにくらベ て求核試䞄に対する反応性は低いから，基質としては比較的反応 性の高い莫化ベンジルおよびその核㯰換誘導体をえらんた。。

非プロトン性極性溶媒として DMFを用い, フッ化カリウム存 在下に臭化ベンジルとへキサフルオロアセトン(1.3〜1.4 mol) を 加圧下に反心させた。塩化ベンゾイルの場合と異なり， $0^{\circ} \mathrm{C}$ 付近 の低温ではほとんと反応が起こらず原料を回收するにととまっ

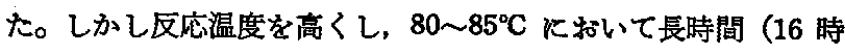
間）反応させると $70 \%$ の取率で目的とするベンジルニヘプタフル オロイソプロピルニエーテルを得ることができた。すなわらこの 場合は，ハロゲン化ベンゾイルとの反応にくらべて生成系が熱力 学的に安定であるため反応温度を高くする方が反応を完結させる のに效果的であることがわかった。ここに得られたベンジルニへ プタフルオロイソプロピルニエーテルは安息香酸エステルと異な り，酸や塩基飞対して十分に安定で，たとえば $10 \%$ 水酸化ナト リウム水溶液中，または $10 \%$ 塩酸中 $100^{\circ} \mathrm{C}$ において 24 時間かき まぜてもはとんど変化なく原料が回収ミれた。

合成中間物としての有用性を検討する目的で，ベンゼン核に㯰 換基をるつベンジルニヘプタフルオロイソプロピルニエーテルを得 るために各種の核㯰換臭化ベンジルとへプタフルオロイソプロポ キシドイオンとの反応を同様にして行なってみた。その結果を表 2 に示した。

一般にハロゲン化ベンジルに対する $S_{\mathrm{N}} 2$ 型の反応は，ベンゼ ン核置換基の影響を受けることが少ないとされている゚。

著者らの結果す, 電子求引性の基をるつ真化ニトロベンジルか らす電子供与性の基をるつ臭化メチルベンジルからす，無䩉換の 臬化ベンジルに対する場合と大差なく収率 70〜85\% でへブタフ ルオロイソプロピルエーテルが得られた。

5) A. G. Pittman, D. L. Sharp, R. E. Lundin, J. Polym. Sci., 4, $2637(1966)$.

6) たとえば, J. March, "Advanced Organic Chemistry : Reactions, Mechanisms and Structure", McGraw-Hill (1968) p. 286 ; 阔本邦男, “講座 有機反応機構, 求核置換 反応”, 東京化学同人 (1969) p.73. 
Table 2 Preparation and spectral properties of benzyl heptafluoroisopropyl ethers

\begin{tabular}{|c|c|c|c|c|c|c|c|c|}
\hline \multirow{2}{*}{$\mathrm{X}$} & \multirow{2}{*}{$\begin{array}{l}\text { Yield } \\
(\%)\end{array}$} & \multirow{2}{*}{$\begin{array}{c}\mathrm{bp} \\
\left({ }^{\circ} \mathrm{C} / \mathrm{mmHg}\right)\end{array}$} & \multicolumn{2}{|c|}{ F-Anal. (\%) } & \multicolumn{2}{|c|}{$\operatorname{IR}\left(\mathrm{cm}^{-1}\right)$} & \multicolumn{2}{|c|}{${ }^{10} \mathrm{~F} \operatorname{NMR}(\mathrm{ppm})^{a)}$} \\
\hline & & & Found & Calcd. & $\mathrm{C}-\mathrm{O}-\mathrm{C}$ & $\mathrm{C}-\mathrm{F}$ & $\mathrm{OCF}$ & $\mathrm{CF}_{8}$ \\
\hline $\mathbf{H}$ & 70 & $93.5 / 83$ & 48.59 & 48.2 & 1100 & $\begin{array}{l}1170 \\
1230\end{array}$ & +28.9 & -33.5 \\
\hline$p-\mathrm{Me}$ & 69 & $78 / 17$ & 45.67 & 45.9 & 1100 & $\begin{array}{l}1170 \\
1230\end{array}$ & +28.5 & -34.0 \\
\hline$m-\mathrm{F}$ & 69 & $89 / 20$ & 51.8 & 51.7 & 1100 & $\begin{array}{l}1190 \\
1240\end{array}$ & +30.0 & -34.0 \\
\hline$p-F$ & 70 & $90 \sim 92 / 69$ & 51.8 & 51.7 & 1100 & $\begin{array}{l}1170 \\
1240\end{array}$ & +29.8 & -32.8 \\
\hline$m-\mathrm{Cl}$ & 73 & $84 / 16$ & 42.61 & 42.8 & 1100 & $\begin{array}{l}1170 \\
1230\end{array}$ & +29.0 & -34.0 \\
\hline$p-\mathrm{Cl}$ & 86 & $132 / 25$ & 42.61 & 42.8 & 1090 & $\begin{array}{l}1170 \\
1230\end{array}$ & +28.8 & -34.0 \\
\hline$m-\mathrm{NO}_{2}$ & $51^{b)}$ & $128 / 16$ & 42.68 & 41.4 & 1100 & $\begin{array}{l}1170 \\
1230\end{array}$ & +28.8 & -34.2 \\
\hline$p-\mathrm{NO}_{2}$ & $74^{b_{y}}$ & $93 / 77$ & 41.35 & 41.4 & 1100 & $\begin{array}{l}1170 \\
1230\end{array}$ & +30.3 & -32.5 \\
\hline
\end{tabular}

a) Given in $\delta \mathrm{ppm}$ from int. PhF (neat)

b) Yield was determined by GLC using tetralin as an internal standard.

\section{3 置換基としてのへブタフルオロイソブロボキシメチル基}

2.2 で述べたように、ベンジル=ヘプタフルオロイソブロピル= エーテルおよびその着換体が合成できることがわかったが，これ らの化合物に呫けるベンゼン核㯰換基としてのヘブタフルオロイ ソプロポキシメチル基が電子的にどのような効果をるつかを明ら かにするために，この基の置換基定数 $\sigma_{\mathrm{I}}$ および $\sigma_{\mathrm{R}}{ }^{0}$ を ${ }^{19} \mathrm{~F} \mathrm{NMR}$ から算出した。すなわち $p$ 扰よび $m$ ーフルオロベンジル=ヘブタ フルオロイソプロピル=エーテルのベンゼン核のフッ素の化学シ フト值(四塩化炭妾中)をフルオロベンゼンを内部標準として測定 し、これらの值を Taftによって示された $\sigma_{1}, \sigma_{\mathrm{R}}{ }^{0}$ との関係式》に あてはめて計算した結果， $\sigma_{I}=+0.19 ， \sigma_{R}{ }^{0}=-0.01$ の倠を得た。 この值を既報の置換メチル基の值”と比較すると誘起効果として はかなり電子求引性をそな光，その強さは $\mathrm{CH}_{2} \mathrm{Cl}(0.14)$ と $\mathrm{CH}_{2} \mathrm{CN}$ (0.24)の中間位位する。また電子供与性の共役効果は他の虚換 又 キル基に比較してるっとる弱く，ほとんど無視できる。へプタフ ルオロイソプロポキシメチル基全体の電子効果には, ヘプタフル オロイソブロピル基の電子求引性誘起効果がかなり影響をおよぽ していることがわかる。

\section{3 実験}

\section{1 安息香酸ヘプタフルオロイソプロビル}

使用する試薬および溶媒は十分に乾燥した。フッ化カリウムは

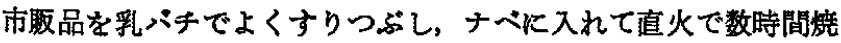
いたのら，さらに手早くすりつぶして使用した。

フッ化カリウム $1.74 \mathrm{~g}(0.030 \mathrm{~mol})$ ，ジグライム $5 \mathrm{ml}$ を耐圧反 伛管中に入れ，反応管を減王にして $-70^{\circ} \mathrm{C}$ 近辺まで温度を下げ， あらかじめトラッブした HFA $5.0 \mathrm{ml}(0.039 \mathrm{~mol})$ を注入し室温 まで上げて溶液が透明になるまでかきまぜた。ついでふたたび反 応管を $-70^{\circ} \mathrm{C}$ 近辺まで下げて塩化ベンゾイル $4.22 \mathrm{~g}(0.030 \mathrm{~mol})$ を注入管を通して入れ，その後注入管を洗らためにジグライム 5

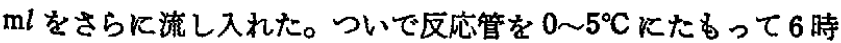
間かきまぜ，反応溶液を水約 $30 \mathrm{ml}$ にあけ，エーテル約 $30 \mathrm{ml}$ で

7) R. W. Taft, E. Price, I. C. Lewis, K. K. Anderson, G. T. Davis, J. Amer. Chem. Soc., 85, 709, 3146(1963).
抽出し，水で洗ったのら硫酸マグネシウムで视燥した。エーテル を留去し，隇压下で蒸留し，bp $72 \sim 73^{\circ} \mathrm{C} / 21 \mathrm{mmHg}$ の安息香酸 ヘプタフルオロイソブロピル $8.15 \mathrm{~g}$ (収率 $93.7 \%$ ) を得た。

分析値 F $46.2 \%$ ，計算倠 F $45.9 \%$

IR : $1780(\mathrm{C}=0), 1100 \sim 1300(\mathrm{C}-\mathrm{F}) \mathrm{cm}^{-1}$

${ }^{19}$ F NMR (neat, 内部標蔀 $\mathrm{PhF}$ ) : $\delta-35.6\left(\mathrm{~d}, \mathrm{CF}_{\mathrm{g}}\right),+27.2$ (sep, OCF) ppm ; $J_{\mathrm{F}-\mathrm{F}} 1.90 \mathrm{~Hz}$

MS : m/e $105\left(\mathrm{PhCO}^{+}\right), 77\left(\mathrm{Ph}^{+}\right), 69\left(\mathrm{CF}_{\mathrm{s}}{ }^{+}\right), 124(\mathrm{Ph} \stackrel{+}{\mathrm{CO}})$, $96\left(\mathrm{RhF}^{+}\right), 290\left(\mathrm{M}^{+}\right)$(強度の順)

なお反応管の溫度を $25^{\circ} \mathrm{C}, 45^{\circ} \mathrm{C}$ にたるった場合には，反応終 了後水にあけると析出する安息香酸の結晶が得られるので沪過し て取り除き，また洗浄した水に湠塩酸を加えて析出した結晶，お よび蒸留の残留物を水酸化ナトリウム水溶液に溶かし塩酸を加え て析出した結晶をあわせて，それそれ $0.61 \mathrm{~g}(17 \%) ， 1.71 \mathrm{~g}(46.6$ \%) の安息香酸を回収した。それそれの場合のェステルの取率は 表 1 に示した。

\section{2 テレフタル酸ジ(ヘブタフルオロイソプロピル)}

フッ化カリウム $2.00 \mathrm{~g}(0.035 \mathrm{~mol})$, ジグライム $30 \mathrm{ml}, \mathrm{HFA}$ $6.0 \mathrm{ml}(0.051 \mathrm{~mol})$, およ゙二塩化テレフタロイル $3.51 \mathrm{~g}(0.017$ $\mathrm{mol})$ を用い3.1 と同様にして室温で 23 時間反底させた。反応溶

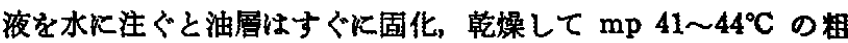
生成物 $7.43 \mathrm{~g}$ (収率 $87 \%$ ) を得た。ベンゼン溶媒によるシリカゲ ルカラムクロマトグラフによって精製し, $\mathrm{mp} \mathrm{40} \sim 42^{\circ} \mathrm{C}$ の板状結 晶を得た。

分析值 F $52.7 \%$ ，計算値 F 53.0\%

IR : $1780(C=0), \quad 1100 \sim 1300(C-F) \mathrm{cm}^{-1}$

${ }^{19} \mathrm{~F} \mathrm{NMR}$ (内部梠準 $\mathrm{PhF}$, 溶某 $\mathrm{CCl}_{4}$ ) : $\delta-36.1\left(\mathrm{CF}_{3}\right),+28.5$ (OCF) ppm

MS : $m / e 502\left(\mathrm{M}^{+}\right), 317\left(\mathrm{M}^{+}-\mathrm{OC}_{3} \mathrm{~F}_{7}\right)$

\section{3 置換臭化ベンジル}

臭化ベンジル，臭化 $p$-メチルベンジル（市㤆品）以外はすべて トルエンの核㯰換体を光および熱によって臭素化して合成した。 以下に各臭化ベンジルの沸点ょよび䖲点を示す。カッコ内の数值 は文献値を示す。 
臭化 pーフルオロベンジル：bp $73^{\circ} \mathrm{C} / 7 \mathrm{mmHg}\left(75 \sim 76^{\circ} \mathrm{C} / 11\right.$ $\mathrm{mmHg})^{8)}$; 奥化 $m$-フルオロベンジル : bp $79^{\circ} \mathrm{C} / 13 \mathrm{mmHg}\left(80^{\circ} \mathrm{C} /\right.$ $13 \mathrm{mmHg})^{8)}$; 臭化 $p$-クロロベンジル : mp 50 $51^{\circ} \mathrm{C}$ (石油エーテ ルから) $\left(50^{\circ} \mathrm{C}\right)^{9)}$; 莫化 $m$ ークロロベンジ：bp 108 110 $\mathrm{C} / 12$ $\mathrm{mmHg}\left(55^{\circ} \mathrm{C} / 0.2 \mathrm{mmFg}\right)^{9)}$; 具化 $p^{-}=$トロベンジル : $\mathrm{mp} 98 \sim 99$

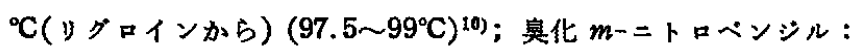

8) J. R. Sampey, A. K. CoCu, J. Amer. Chem. Soc., 72, 3814(1950) ; J. Bernstein, J. S. Roth, W. J. Miller, Jr., ibid., 70, 2310(1948).

9) F. Kröhnke, Chem. Ber., 83, 35(1950).

10) “Org. Syntheses", Coll. Vol.2, p. 444(1943).

11) F. Kröhnke, H. Schmeiss, W. Gottstein, Chem. Ber., 84, 131 (195i).

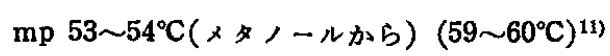

$$
3.4 \text { ベンジル=ヘブタフルオロイソプロピル=エーテル類 }
$$

フッ化カリウム $1.50 \mathrm{~g}(0.026 \mathrm{~mol}), \mathrm{DMF} 10 \mathrm{ml}$, HFA $4.0 \mathrm{ml}$ $(0.033 \mathrm{~mol})$ および臭化ベンジル類 $0.026 \mathrm{~mol}$ 用いて 3.1 と同様 に反芯を行なった。核置換臭化ベンジルを注入するさい，これが 液体の場合には，注入管を $10 \mathrm{~m} l$ の DMF で洗い，結晶の場合に は $5 \mathrm{ml}$ の DMFに溶かし $5 \mathrm{ml}$ で洗らようにして, DMFの量を全 体で $20 \mathrm{ml}$ Kなるようにした。反応管は温度 $80 \sim 85^{\circ} \mathrm{C}$ にたるち 16 時間かきまぜた。反応後は反応溶液を水に注ぎ，エーテルで 抽出しさらに 2 回水洗して硫酸マグネシウムで乾蜗した。乾燥後 エーテルを留去し, 残留物を蒸留することによって生成物を得 た。生成物の収量, 沸点, IR, NMR データなどは表 2 に示した。

\title{
Preparation and Properties of Heptafluoroisopropyl Benzoate and Benzyl Heptafluoroisopropyl Ethers
}

\author{
Nobuo Ishikawa and Tadashi Osawa \\ Department of Chemical Engineering, Tokyo Institute of \\ Technology ; Ookayama, Meguro-ku, Tokyo 152 Japan
}

The reaction between benzoyl halide and heptafluoroisopropoxide ion, derived from hexafluoroacetone and fluoride ion, was thermodynamically controlled and gave unstable heptafluoroisopropyl benzoate at a low temperature such as $0^{\circ} \mathrm{C}$ (Table 1 ).

$$
\begin{aligned}
& \left(\mathrm{CF}_{3}\right)_{2} \mathrm{C}=\mathrm{O}+\mathrm{F}^{-} \rightleftarrows\left(\mathrm{CF}_{3}\right)_{2} \mathrm{CF}-\mathrm{O}^{-} \\
& \mathrm{Ph}-\mathrm{COX}+\left(\mathrm{CF}_{3}\right)_{2} \mathrm{CF}-\mathrm{O}^{-} \rightleftarrows \mathrm{Ph}_{-} \mathrm{CO}_{2} \mathrm{CF}\left(\mathrm{CF}_{3}\right)_{2}+\mathrm{X}^{-}
\end{aligned}
$$

In contrast with this, the similar reaction with benzyl halide required a higher temperature, $80 \sim 85^{\circ} \mathrm{C}$, and stable benzyl heptafluoroisopropyl ether was afforded in a good yield.

$$
\mathrm{Ph}-\mathrm{CH}_{2} \mathrm{X}+\left(\mathrm{CF}_{3}\right)_{2} \mathrm{CF}-\mathrm{O}^{-} \longrightarrow \mathrm{PhCH}_{2}-\mathrm{O}-\mathrm{CF}\left(\mathrm{CF}_{3}\right)_{2}+\mathrm{X}^{-}
$$

Other ring-substituted benzyl halides reacted under the similar condition, and $p$-methyl- and $m$ - and $p$-fluoro-, chloro- and nitrobenzyl heptafluoroisopropyl ethers were obtained in the fair yields (Table 2).

On the basis of the ${ }^{18} \mathrm{~F}$ NMR chememical shifts of $m$ - and $p$-fluoro derivatives, the $\sigma_{R}{ }^{0}$ and $\sigma_{1}$ values for $\mathrm{CH}_{2} \mathrm{OCF}\left(\mathrm{CF}_{3}\right)_{2}$ group were determined to be -0.01 and +0.19 respectively. 